\title{
Developing Graduate Students' Self-Regulation and Critical Thinking During a Clinical Writing Workshop
}

\author{
Whitney Schneider-Cline \\ University of Nebraska Kearney, schneiderwm@unk.edu \\ DOI: doi.org/10.30707/TLCSD1.1Schneider-Cline
}

Follow this and additional works at: https://ir.library.illinoisstate.edu/tlcsd

Part of the Scholarship of Teaching and Learning Commons

\section{Recommended Citation}

Schneider-Cline, Whitney (2017) "Developing Graduate Students' Self-Regulation and Critical Thinking During a Clinical Writing Workshop," Teaching and Learning in Communication Sciences \& Disorders: Vol. 1: Iss. 1, Article 3.

DOI: doi.org/10.30707/TLCSD1.1Schneider-Cline

Available at: https://ir.library.illinoisstate.edu/tlcsd/vol1/iss 1/3

This Scholarship of Teaching and Learning Research is brought to you for free and open access by ISU ReD: Research and eData. It has been accepted for inclusion in Teaching and Learning in Communication Sciences \& Disorders by an authorized editor of ISU ReD: Research and eData. For more information, please contact ISUReD@ilstu.edu. 


\title{
Developing Graduate Students' Self-Regulation and Critical Thinking During a Clinical Writing Workshop
}

\author{
Abstract \\ Clinical writing is a significant component of being an effective speech-language pathologist, yet often \\ clinicians are not formally trained in this area. Limited evidence exists regarding how to address this \\ problem. Within the current study, graduate speech-language pathology students participated in a Clinical \\ Writing Workshop (CWW) specifically aimed at improving self-regulation and critical thinking as \\ demonstrated through professional writing improvement. The CWW consisted of weekly meetings for the \\ course of one academic semester; each meeting targeted a specific clinical writing topic related to style/ \\ use (related to self-regulation) and/or content (related to critical thinking). Participants $(n=17)$ \\ completed the intervention and provided pre- and post-treatment questionnaires, writing samples and \\ interviews to demonstrate change. Results of this mixed methods study indicate that the CWW, and more \\ specifically the use of models, explicit instruction, writing practice, and feedback, positively impacted \\ participants' self-regulation and critical thinking skills related to clinical writing.
}

\section{Keywords}

Clinical writing, writing workshop, explicit instruction, self-regulation, critical thinking 
Clinical writing is an essential skill for speech-language pathologists, as it is representative of the clinician and the services provided (Burrus \& Willis, 2013; Pannbacker, 1975). Clinicians' poor clinical writing may indicate to other professionals that the writer lacks content knowledge. Therefore, strong clinical writing skills are necessary to establish a clinician's credibility professionally. Furthermore, the value of clinical writing is represented in the notion that writing style reflects the clinician's view of the clinical process and of the client; writing style impacts a clinician's choice of words, organization and consideration of the reader (Wilkerson, 2000). Each of these areas is crucial for success in clinical writing, and working with clients in general. Based on the impact clinical writing style can have, it is important for professionals to write clearly by avoiding ambiguity, using detail including appropriate terminology for the audience, being succinct, and striving to avoid evoking emotional responses from readers. These skills are unique to clinical writing for speech-language pathologists and further promote the need for instruction within this area to insure student success.

Clinical writing expectations are high for graduate students studying speechlanguage pathology; they are required to engage in clinical writing assignments, and it is commonly the case that students are expected to be proficient in this new genre of writing despite the fact that little formal instruction has been provided (Burrus \& Willis, 2013; Sitler, 1993). Baxley and Bowers (1992) indicated that nearly $3 / 5$ of clinical supervisors claimed that their programs offer no formal instruction directed at clinical writing skills, and that students reported receiving no such training. In order for students to master professional writing, they need instruction regarding the specific features of their profession's writing; however, formal efforts to do so are rare (Burrus \& Willis, 2013; Smith, Ariail, RichardsSlaughter, \& Kerr, 2011). Because little instruction is being provided to support the development of clinical writing skills in graduate speech-language pathology students, frustration is often the result (Hegde, 2010). Instruction that does occur is often embedded into coursework and periodically addressed by clinical supervisors (Baxley \& Bowers, 1992). Without sufficient opportunities for practice to learn clinical writing skills, speech-language pathology graduate students are not prepared for future employment (Hegde, 1994).

The current study was designed to address the need for specific clinical writing instruction for graduate students studying speech-language pathology. More specifically, the study was intended to address cognitive components such as selfregulation and critical thinking, as growth within these two areas is fundamental for building clinical writing skills. 


\section{Self-Regulation}

Self-regulation is a process; it requires learners to direct their own thoughts, allowing them to apply their cognitive efforts towards specific skills (Zimmerman, 2002). Within this process, individuals are an active, guiding component of their learning. Self-regulated learning occurs as a result of students focusing their thoughts and actions towards their educational goals (Schunk, 1989). In addition, students possessing self-regulatory skills are aware of their abilities and are able to monitor their progress and adjust accordingly (Loyens, Magda, \& Rikers, 2008; Zimmerman, 2002). Such analytical abilities are key for students to improve their clinical writing skills and transfer these skills to actual clinical settings during graduate school and beyond.

Zimmerman and Schunk (2011) provide an overview of historical evidence suggesting that self-regulated learning is a valid means for improving student achievement. Beginning graduate speech-language pathology students often have limited experience with clinical writing; this population, therefore, could benefit from self-regulated learning within this domain. Furthermore, Zimmerman (2002) identified the importance of self-regulation in developing life-long learners. Becoming a life-long learner is certainly emphasized in graduate school. Graduate speech-language pathology students must be prepared to continue learning and adapting their skills to the demands of their clients and work settings. This is especially true when considering clinical writing. Students must learn to selfmonitor and evaluate their clinical writing during graduate school given supervisor feedback, so they are prepared to do so when working with clients independently in the future.

While the benefits of self-regulated learning are evident regarding student achievement and the creation of life-long learners, self-regulation is also important when considering the area of writing in general. Within this context, the complexity of self-regulation becomes clear. Zimmerman and Bandura (1994) suggest that this complexity is due to the fact that writing is often completed independently, at a time convenient for the writer, and requires editing and revision. These requirements demonstrate the demanding amount of self-regulation needed to be a successful writer. Clinical writing is no different; students are required to meet deadlines and supervisor expectations, placing extra pressure upon them and furthering the need to build their self-regulatory skills in this area. 


\section{Critical Thinking}

Critical thinking has been defined as, "reasonable reflective thinking focused on deciding what to believe or do" (Ennis, 1989, p. 4). The key elements of this perspective imply that one considers different perspectives and options prior to committing to a decision, which should be foundational during clinical writing. Varying perspectives and options must be considered for clinical writing to be presented clearly and concisely while expressing appropriate content based on client needs. This content includes explanation of pertinent historical evidence, and developing appropriate target goals and objectives that are expressed in a readerfriendly manner. Avoiding the use of professional jargon and carefully contemplating word choice are important considerations for the clinical writing process as well. In order for students to complete professional writing as described, they must engage in critical thinking.

Teaching students to engage in critical thinking is not simple, but writing is a natural medium for doing so. Within the writing process, constant evaluation of information for decision-making is required, indicating the need for critical thinking. In a comparison of four collegiate institutions, Tsui (2002) qualitatively investigated the impact of pedagogy on students' critical thinking skills. The findings suggest development of critical thinking skills is possible through writing tasks as well as via classroom discussion. When considering writing, developing critical thinking skills was linked to the amount and nature of writing and re-writing conducted; assessing others' writing and engaging in re-writing tasks also encouraged critical thinking.

Other, more global justification for building critical thinking skills within graduate speech-language pathology students exist as well. Tsui (2002) stressed the importance of critical thinking skills in preparing students to deal with future challenges both personally and professionally. Students possessing critical thinking skills are better prepared for lifelong learning which, as previously mentioned, is necessary for speech-language pathologists (Terenzini, Springer, Pascarella, \& Nora, 1995; Tsui, 2002). Abrami et al. (2008) align with this belief as they suggest "critical thinkers have a better future as functional and contributing adults" (p. 1103). Those who can think critically will be able to function well personally and professionally, which is, of course, desired for graduate students.

\section{Professional Writing Instruction}

A profession-specific writing course for graduate students is one possible means for improving graduate students' professional writing skills (Rawson, Quinlan, Cooper, Fewtrell, \& Matlow, 2005). Rawson et al. (2005) recognize a lack of 
professional writing skills in graduate medical professional students, specifically Veterinary Medicine Science students. Their study involved six weeks of rigorous writing exercises embedded into an existing course to determine if additional writing practice would impact the quality of students' professional writing. Participants showed improved ability to use medical terminology appropriately in writing, yet the authors concluded that additional professional writing practice was necessary for proficient professional writing level achievement.

In addition, teaching writing in content areas can also lead to significant improvements in student writing (Fallahi, Wood, Austad, \& Fallahi, 2006). Fallahi et al. (2006) examined the effects of writing instruction provided within undergraduate general psychology courses. Opportunities for in-class writing instruction, peer editing, writing practice and specific, timely feedback were provided. Participants demonstrated significant improvements within the areas of grammar, writing style, mechanics and American Psychological Association referencing style across one semester.

Alternate means exist for addressing the development of writing skills, in general, for speech-language pathology undergraduate students. Plante $(2010,2011)$ argues that one class addressing writing skills is not enough; development of a departmental writing curriculum and knowledge of best practices in writing instruction, however, are instrumental to developing students' writing skills. Specifically, in consideration of best practices, the writing instruction principles of Butler and Silliman (2002) are referenced; these features include: a) models, (b) writing practice, (c) explicit instruction, and (d) feedback.

\section{Research Questions}

This study was designed to address graduate speech-language pathology students' clinical writing skills by testing the effects of an intervention as a means for increasing self-regulation and critical thinking within this domain. The following hypotheses were tested, each stated in connection to the research questions:

1. It was predicted that participants would demonstrate improved selfregulation skills, especially in their ability to monitor their own clinical writing attempts as a result of their participation in the Clinical Writing Workshop (CWW).

2. It was predicted that participants would demonstrate improved clinical writing performance following engagement with the embedded critical thinking tasks of the CWW. 


\section{Method}

\section{Participants and Setting}

Graduate students in their second semester studying speech-language pathology at a Midwest university were invited to participate in the CWW during a spring semester. Seventeen Caucasian female students with a mean age of 24.5 years participated in the study. Participation was voluntary, and consent was required. Participants were asked to attend weekly 50-minute CWW meetings over the course of one semester. Meetings were conducted on campus in a classroom and within a Health Insurance Portability and Accountability Act (HIPAA)-protected computer lab (to insure protection of clients' identity and personal information).

\section{Procedures}

Pre-Intervention Data Collection. Data collection prior to the intervention included a questionnaire, interviews and participant writing samples. The preintervention Clinical Writing Questionnaire ( $C W Q$, see Appendix A) was a paperpencil task requesting participants identify specific goals they had for the CWW and to improve their clinical writing skills. The items on this questionnaire were intended to provide information about each participant's feelings towards clinical writing, and to help the author better understand their experience in clinical writing.

Two participants were randomly selected (e.g. their names were drawn out of a hat) to participate in one-on-one interviews in order to capture a more thorough portrayal of the topics presented in the pre-intervention questionnaire (see Appendix A for interview questions). Interviews were completed by a graduate assistant trained by the author in order to obtain more open, honest responses from participants. Interviews were conducted in a private room on campus and lasted less than ten minutes each. The interviews were audio recorded and then transcribed by the graduate assistant who conducted them.

The writing samples collected consisted of an initial therapy report completed by each participant for a clinical assignment at the beginning of the same semester as the CWW. The participants were provided a template for this assignment, as well as examples of previously completed reports matching the desired format. The reports were to contain the following sections: Demographic Information, Complaint and Referral, Current Status, Goals and Objectives, and Procedures. Two certified speech-language pathologists rated the writing samples using the Clinical Writing Rubric ( $C W R$, see Appendix B) to quantify each participant's clinical writing skill. Both of the raters had experience in clinical supervision, which included rating students' clinical writing in areas similar to those of the 
$C W R$. The rubric ratings were utilized to represent participants' clinical writing skills related to self-regulation and critical thinking. The first section of the rubric, "Use (Clinical Writing Style)," contained items related to demonstration of selfregulation during clinical writing. Skills such as using active voice, and writing objectively represent self-regulation, as they required participants to actively engage in the clinical writing process, direct their own thoughts while doing so, and monitor their writing; these acts closely align with existing definitions of selfregulation (Loyens, et al., 2008; Schunk, 1989; Zimmerman, 2002). The final sections of the rubric, "Content" and "Form," (combined and furthermore referred to as "Content") contained items related to demonstration of critical thinking during clinical writing. Participants' ability to include relevant background information and provide appropriate rationale for their goals within their clinical writing demonstrates "reasonable reflective thinking focused on deciding what to believe or do" (Ennis, 1989, p. 4). Each target area within the rubric was rated on a scale from 1 (Standard not met within this document) to 5 (Standard met consistently throughout the document); ratings of 0 indicated an item was "Not Applicable." The raters first independently rated each sample, and then met to compare ratings and to ensure satisfactory inter-rater reliability with a Cohen's Kappa value of 0.8 or greater, a widely accepted criterion for this value (Hallgren, 2012). The preintervention writing samples and their ratings from the $C W R$ were used to establish a baseline for participant performance prior to intervention.

Intervention. Following the collection of pre-treatment measures, intervention consisted of one 50-minute session per week for a 12-week period over the course of a semester. Intervention was presented in the CWW for speech-language pathology graduate students interested in improving their clinical writing skills. The workshop progressed over the course of the semester through the target areas outlined on the $C W R$. Topics were specifically addressed for one or two weeks each, and then continually referenced as applicable during additional weeks focusing on new topics (see Appendix C for complete CWW schedule outlining topics addressed).

Butler and Silliman's (2002) principles (i.e., models, writing practice, explicit instruction, and feedback) have proven efficacious within the literacy treatment literature; therefore, the effects of these features were considered in development of the current study. For example, each topic was introduced initially through explicit instruction. Lessons provided specific information about expectations and guidelines regarding the target skill(s) for this period. During the instructional phase, information was presented and examples (models) were provided to support lessons. Following the instructional phase, students were provided an opportunity to practice the target skill (writing practice); this took place during the same meeting as the instructional phase. Practice opportunities included tasks such as 
editing provided writing samples, and generating novel writing samples. The participants then had the opportunity to participate in guided critiques of each other's writings; the critiques were guided in the sense that specific topics were provided for participants to consider and comment on while independently reviewing other participants' writing. For example, if the topic of the week was 'writing concisely,' participants were encouraged to focus their feedback within this area (additional comments regarding previously addressed topics was also encouraged). Following such critiques, the students could make revisions to their writing samples. During these revisions, the instructor provided feedback and answered individual participant questions. At the end of each topic, participants could submit their writing sample; written feedback was provided for each submitted sample regarding the target skill as well as previously covered topics. This pattern progressed for the course of the semester, with each session building from the previous, and each writing sample becoming progressively more critically evaluated based on the increasing criteria.

Post-Intervention Data Collection. At the conclusion of the intervention, participants were asked to provide another clinical writing sample. This consisted of an end-of-semester therapy report for a client that the participant worked with over the course of the semester (the same client that participants wrote about preintervention). This report was similar to the pre-intervention writing sample, but it was updated to reflect changes that occurred over the semester and also included the following sections: Results and Recommendations. The same two speechlanguage pathologists who had rated the pre-intervention writing samples also rated the post-intervention samples using the $C W R$. Additionally, participants completed the post-intervention $C W Q$ (see Appendix A). The post-intervention questionnaire asked participants to rate their progress towards their personal goals established prior to the intervention, as well as share their feelings towards the workshop. Identifying progress towards previously established goals relates to self-regulation during clinical writing tasks (Schunk, 1989). In addition, one-on-one interviews were conducted with two randomly chosen participants following the intervention and post-test measures in order to gain a stronger understanding of how successful the workshop was and how participants viewed the experience (see Appendix A for Interview Questions).

Qualitative Data Collection and Analysis Procedures. Throughout the duration of the CWW, in addition to the $C W Q s$ (pre- and post-intervention) and interviews with two randomly selected participants (pre- and post-intervention) qualitative data were also collected via field notes documented throughout the intervention by the author. The field notes were composed during and immediately following each workshop meeting documenting the specific areas that were addressed throughout the intervention. Comments and questions posed by participants as well as general 
observations made throughout were included, and were intended to help capture the participants' feelings, attitudes and impressions from this experience.

The author analyzed all qualitative data. Once these data were collected and transcribed, the author read through the data to gain a general sense of the material. Next, the text segments were coded, and labeled in an effort to capture the main concepts present. These codes were used to organize themes identified from the data, which were then utilized for comparison with the quantitative data collected.

Validation strategies for the data collected included triangulation and disconfirming evidence (Creswell \& Plano Clark, 2011). Triangulation of data involves development of support for a theme drawn from several sources (Creswell \& Plano Clark, 2011); in this study, triangulation of data collected from participant questionnaires, interviews, and the author's field notes allowed for a more representative account of the data represented in the identified themes. Disconfirming evidence contradicts evidence established; this confirms the accuracy of the data, as realistically not all data will diverge cleanly into positive information (Creswell \& Plano Clark, 2011). Within this study, disconfirming evidence present within the collected qualitative data also indicates validity as some variability in results is expected. Some participants indicated varying views from those captured by the majority, indicating that realistic data was captured.

\section{Results}

\section{Quantitative Data}

CWR Ratings. Ratings for clinical writing use from both raters were compared to insure reliability. Two-way mixed effects model intraclass correlation coefficients for pre- and post-intervention writing rubric ratings for use ( 7 items) indicated very high agreement between the two raters (pre-intervention agreement $=1.00$; postintervention agreement $=0.99$, Cronbach's alpha). Ratings for clinical writing content ( 9 items) were also analyzed in this manner, and, again, a high level of agreement was indicated between the two raters (pre-intervention agreement $=$ 0.97; post-intervention agreement $=1.00$, Cronbach's alpha). 
Table 1

Mean Pre- and Post-Intervention Combined CWR Ratings

\begin{tabular}{lll}
\hline & $\begin{array}{l}\text { Pre-Intervention } \\
M(S D)\end{array}$ & $\begin{array}{l}\text { Post-Intervention } \\
\text { M (SD) }\end{array}$ \\
\hline Use Ratings & $4.02(0.39)$ & $4.17(0.36)$ \\
\hline Content Ratings & $2.64(0.34)$ & $3.55(0.52)$
\end{tabular}

The two raters' data were combined for further analyses; combined pre- and postintervention $C W R$ rating means for use and content are presented in Table 1 . These rating data then were analyzed using SAS software, as multilevel models were generated in consideration of all data collected (e.g., participants who only completed writing samples at one time point were all included in the analysis). For clinical writing use, these analyses indicated that while effects for time (pre- and post-intervention) and attendance (number of sessions attended) were both positive, neither was significant (time: $\mathrm{F}(1,15.3)=4.09, \mathrm{p}=.061$; attendance: $\mathrm{F}(1,14.7)=$ $.25, \mathrm{p}=.62)$. For clinical writing content, these analyses indicated that the effect of time (pre- to post-intervention; $\mathrm{F}(1,15.6)=314.98, \mathrm{p}=<.001$ ) was significant, but that the effect of attendance was not $(F(1,14.9)=0.01, p=.93)$.

\section{Qualitative Data}

Qualitative data were collected via the $C W Q s$ (pre- and post-intervention) from all participants (pre- $n=17$, post- $n=14$ ) as well as from interviews with two randomly selected participants (pre- and post-intervention) and through field notes documented throughout the intervention by the author. Analysis of all qualitative data gathered revealed three themes. A summary of these themes is provided in Table 2; each of the themes are more specifically presented in the following sections.

Participant Strengths and Weaknesses: Opinions before Completing the CWW. A wide variety of participant needs emerged when exploring participants' self-perceived strengths and weaknesses within the clinical writing genre as identified in pre-intervention questionnaires and interviews. One participant indicated no perceived strengths within this domain, while others identified specific areas related to clinical writing use, content and general writing skills as areas of relative strength. Participants' pre-intervention self-identified areas of strength within the clinical writing domain are summarized in Table 3. Areas of selfidentified weaknesses within clinical writing also focused primarily on areas Table 2 
Summary of Qualitative Themes

\begin{tabular}{|c|c|c|c|}
\hline Theme & Data Source & Overview & Purpose \\
\hline $\begin{array}{l}\text { Participant } \\
\text { Strengths and } \\
\text { Weaknesses }\end{array}$ & $\begin{array}{l}* \text { Pre-intervention } \\
\text { CWQ } \\
\text { *Pre-intervention } \\
\text { interviews }\end{array}$ & $\begin{array}{l}\text { Data within this theme } \\
\text { revealed: participants' } \\
\text { self-identified strengths } \\
\text { and weaknesses, personal } \\
\text { goals specific to clinical } \\
\text { writing prior to } \\
\text { intervention }\end{array}$ & $\begin{array}{l}\text { *Capture participants' } \\
\text { feelings and beliefs towards } \\
\text { clinical writing before } \\
\text { intervention participant } \\
\text { *Each es ablished clinical writing } \\
\text { establish } \\
\text { goals (provide opportunity } \\
\text { for self-regulation of these } \\
\text { target areas throughout) }\end{array}$ \\
\hline $\begin{array}{l}\text { Intervention } \\
\text { Features }\end{array}$ & $\begin{array}{l}\text { *Author's field } \\
\text { notes }\end{array}$ & $\begin{array}{lr}\text { Data within this theme } \\
\text { revealed: } & \text { observed } \\
\text { demonstration } & \text { of } \\
\text { participants' } & \text { self- } \\
\text { regulation and critical } \\
\text { thinking during clinical } \\
\text { writing tasks }\end{array}$ & $\begin{array}{l}\text { *Explains opportunities } \\
\text { within the intervention for } \\
\text { specific demonstration of } \\
\text { and growth within self- } \\
\text { regulation and critical } \\
\text { thinking skills related to } \\
\text { clinical writing }\end{array}$ \\
\hline Outcomes & $\begin{array}{l}\text { *Post-intervention } \\
\text { CWQ } \\
\text { *Post-intervention } \\
\text { interviews }\end{array}$ & $\begin{array}{l}\text { Data within this theme } \\
\text { revealed: changes in } \\
\text { participants' clinical } \\
\text { writing from pre- to post- } \\
\text { intervention; progress } \\
\text { towards personal clinical } \\
\text { writing goals }\end{array}$ & $\begin{array}{l}\text { *Describes participants' } \\
\text { perceived growth following } \\
\text { intervention } \\
\text { *Demonstrates change in } \\
\text { self-regulation, critical } \\
\text { thinking skills related to } \\
\text { clinical writing }\end{array}$ \\
\hline
\end{tabular}

Table 3

Participants' Pre-Intervention Perceived Clinical Writing Strengths

\begin{tabular}{|c|c|c|}
\hline $\begin{array}{l}\text { General Area } \\
\text { of Strength }\end{array}$ & $\begin{array}{l}\text { Specific Skills (Identified as clinical } \\
\text { writing strength) }\end{array}$ & Evidence \\
\hline $\begin{array}{l}\text { Clinical " } \\
\text { Writing "Use" } \\
\text { (demonstration } \\
\text { of self- } \\
\text { regulation) }\end{array}$ & 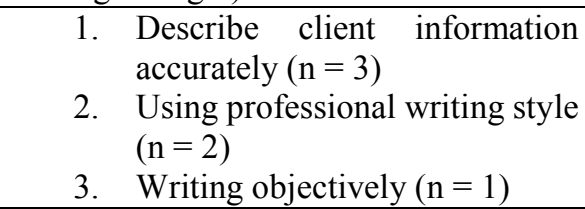 & $\begin{array}{l}\text { Alice: I feel I am well prepared to } \\
\text { summarize, describe, and report } \\
\text { appropriate information. I } \\
\text { understand the objectivity in } \\
\text { clinical writing. }\end{array}$ \\
\hline $\begin{array}{l}\text { Clinical } \\
\text { Writing } \\
\text { "Content" } \\
\text { (demonstration } \\
\text { of critical } \\
\text { thinking) } \\
\end{array}$ & 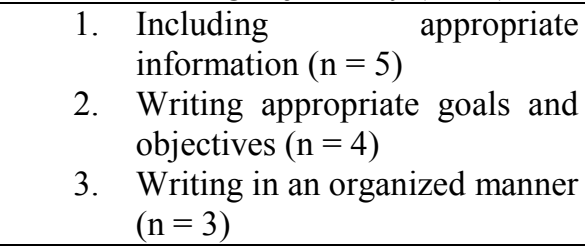 & $\begin{array}{l}\text { Fran: I have ideas of what needs to } \\
\text { go into a report and where that } \\
\text { information should go. }\end{array}$ \\
\hline $\begin{array}{l}\text { Other (general } \\
\text { writing } \\
\text { mechanics) }\end{array}$ & $\begin{array}{ll}\text { 1. } & \text { Use of conventions }(\mathrm{n}=1) \\
\text { 2. } & \text { Writing in third person }(\mathrm{n}=1) \\
\text { 3. } & \text { Spelling }(\mathrm{n}=1) \\
\text { 4. } & \text { Grammar }(\mathrm{n}=1)\end{array}$ & \\
\hline
\end{tabular}


of use and content, but additional, general concerns about clinical writing surfaced as well. Table 4 provides an overview of participants' perceived pre-intervention areas of weakness within clinical writing.

Table 4

Participants' Pre-Intervention Perceived Clinical Writing Weaknesses

\begin{tabular}{|c|c|c|}
\hline $\begin{array}{l}\text { General Area of } \\
\text { Weakness }\end{array}$ & $\begin{array}{l}\text { Specific Skills (Identified as clinical } \\
\text { writing weakness) }\end{array}$ & Evidence \\
\hline $\begin{array}{l}\text { Clinical Writing } \\
\text { "Use" } \\
\text { (demonstration } \\
\text { of weakness in } \\
\text { self-regulation) }\end{array}$ & $\begin{array}{ll}\text { 1. } & \text { Appropriate } \\
\text { vocabulary/professional word } \\
\text { choice }(\mathrm{n}=10) \\
\text { 2. Writing concisely }(\mathrm{n}=5) \\
\text { 3. Using professional writing } \\
\text { style }(\mathrm{n}=4) \\
\text { 4. Writing in active voice }(\mathrm{n}=3)\end{array}$ & $\begin{array}{l}\text { Erica described her area of } \\
\text { weakness as: being concise while } \\
\text { including all necessary } \\
\text { information and using } \\
\text { professional terminology. } \\
\text { Nora: I lack a professional vocab } \\
\text { sometimes when writing and don't } \\
\text { always word the reports in the } \\
\text { best way. }\end{array}$ \\
\hline $\begin{array}{l}\text { Clinical Writing } \\
\text { "Content" } \\
\text { (demonstration } \\
\text { of weakness in } \\
\text { critical thinking) }\end{array}$ & $\begin{array}{l}\text { Failure to include strong goals } \\
\text { and objectives }(\mathrm{n}=4) \\
\text { 2. Including pertinent client } \\
\text { information }(\mathrm{n}=4)\end{array}$ & $\begin{array}{l}\text { Piper described her clinical } \\
\text { writing area of concern as: } \\
\text { Making the appropriate goals and } \\
\text { how to collect data for them. } \\
\text { Fran stated her weakness as: Not } \\
\text { knowing what exactly needs to go } \\
\text { in a report and how to say it } \\
\text { professionally. }\end{array}$ \\
\hline Other & 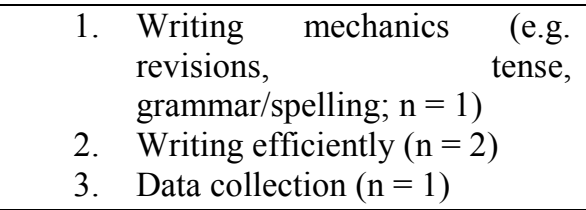 & \\
\hline
\end{tabular}

Based on their self-proclaimed areas of clinical writing weakness, each participant established specific pre-intervention goals for the intervention. Specific areas addressed in participants' initial goals for the intervention included areas such as clinical writing use, content, self-efficacy and areas of general writing skills. An overview of participants' goals is presented in Table 5. 
Table 5

Participants' Clinical Writing Goals

\begin{tabular}{|c|c|c|}
\hline General Goal & Clinical Writing Target Skill & Evidence \\
\hline $\begin{array}{l}\text { Clinical } \\
\text { Writing "Use" } \\
\text { (demonstration } \\
\text { of weakness in } \\
\text { self-regulation) }\end{array}$ & 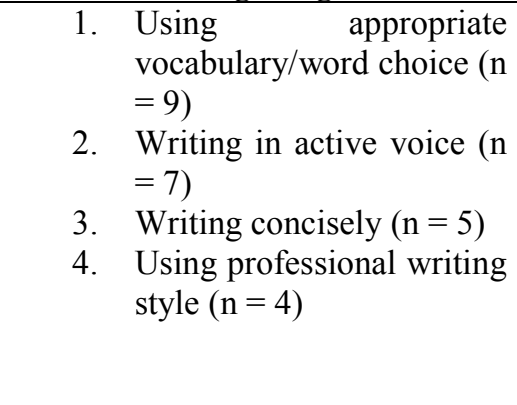 & $\begin{array}{l}\text { Erica's list of goals for the semester } \\
\text { included: learning how to write in active } \\
\text { versus passive voice, being concise in } \\
\text { clinical writing, and learning/ } \\
\text { incorporating professional terminology. } \\
\text { Gina: I would like to better my } \\
\text { vocabulary and learn how to write } \\
\text { professionally when writing about my } \\
\text { clients'goals, progress, reports, etc. }\end{array}$ \\
\hline
\end{tabular}

Quinn's goal was to learn: how to use simplified clinical writing that still gives other professionals a lot of information.

\begin{tabular}{|c|c|c|c|}
\hline of & & $\begin{array}{l}\text { Writing stronger goals and } \\
\text { objectives }(\mathrm{n}=4) \\
\text { Including pertinent client } \\
\text { information }(\mathrm{n}=3) \\
\text { Being able to write } \\
\text { appropriately for different } \\
\text { clinical settings/audiences } \\
(\mathrm{n}=2) \\
\text { Interpreting results } \\
\text { accurately; Being able to } \\
\text { synthesize writing; } \\
\text { Writing stronger lesson } \\
\text { plans; Better organized } \\
\text { writing; }(\mathrm{n}=1)\end{array}$ & $\begin{array}{l}\text { Heather, stated that her goals included: } \\
\text { Understanding what information should } \\
\text { be included and excluded when writing } \\
\text { initial and final semester reports versus } \\
\text { diagnostic reports. } \\
\text { Lori indicated that one of her goals was } \\
\text { to become: more proficient at writing } \\
\text { measureable goals and objectives. } \\
\text { One of Rose's goals was to become: } \\
\text { aware of what information needs to be } \\
\text { provided in reports. }\end{array}$ \\
\hline
\end{tabular}

\section{Intervention Features: How were self-regulation and critical thinking} addressed during the Clinical Writing Workshop? Field notes documented the specific areas that were addressed throughout the intervention. Furthermore, this data describes how the intervention plan for targeting self-regulation and critical thinking skills was executed. Table 6 provides examples of how participants' selfregulation and critical thinking skills were documented as significant cognitive aspects of the intervention (via the field notes collected). 
Table 6

Intervention Features Documented in Field Notes

\begin{tabular}{|c|c|}
\hline $\begin{array}{l}\text { Cognitive } \\
\text { Component }\end{array}$ & Evidence \\
\hline Regulation & $\begin{array}{l}\text { 1. Application of lessons from intervention present in participants' writing } \\
\text { assignments and while utilizing materials provided for practice opportunities } \\
\text { throughout the workshop. ( } \mathrm{n}=5 \text { sessions) } \\
\text { *This application speaks to the participants' growing ability to monitor their own } \\
\text { progress, a key aspect of self-regulated learning. } \\
\text { 2. Participants applied information from the workshop to generate sections of a } \\
\text { mock diagnostic report given a case study. ( } \mathrm{n}=2 \text { sessions) } \\
\text { 3. During group discussion, participants applied concepts from a strong clinical } \\
\text { report model provided during a previous meeting to address questions they } \\
\text { had during a writing lab session. } \\
\text { *Utilizing these resources across sessions demonstrated the participants' abilities } \\
\text { to focus their efforts towards improving their self-regulation of clinical writing } \\
\text { skills. }\end{array}$ \\
\hline $\begin{array}{l}\text { Critical } \\
\text { Thinking }\end{array}$ & $\begin{array}{l}\text { 1. Participation in class discussions was one of the ways critical thinking was } \\
\text { targeted during the workshop. This was most clearly documented for sessions } \\
\text { that specifically addressed topics such as professional word choice, and } \\
\text { writing a diagnostic report. ( } \mathrm{n}=3 \text { ) } \\
\text { *These discussions demonstrated the participants' ability to reflectively analyze } \\
\text { these aspects of clinical writing and make informed clinical decisions. } \\
\text { 2. Questions were posed throughout the intervention sessions in specific areas } \\
\text { such as use and content. } \\
\text { *Participants' ability to pose such questions demonstrated increased awareness of } \\
\text { these specific clinical writing topics, requiring critical thinking skills, as they were } \\
\text { reflective of explicit instruction within these areas. } \\
\text { 3. Participants critiqued sample reports, sought outside resources for making } \\
\text { professional word choices, and collaborated in problem-solving efforts to } \\
\text { incorporate the use of active voice in their writing. }\end{array}$ \\
\hline
\end{tabular}

Outcomes: What changed as a result of CWW participation? This theme emerged from comparisons of participants' $C W Q$ and interview responses prior to and following the intervention. Participants described changes in their own writing behaviors that would likely indicate improved clinical writing outcomes; specifically, their reports demonstrate growth in self-regulation and critical thinking as applied to clinical writing. Outcomes from the intervention, as described by the participants, are presented in Table 7 . 
Table 7

Participants' Reported Outcomes from the $C W W$

\begin{tabular}{ll}
\hline Outcome & Evidence \\
\hline $\begin{array}{l}\text { Improved clinical writing } \\
\text { skills (in areas of use \& } \\
\text { content) }\end{array}$ & $\begin{array}{l}\text { Bev: The biggest change in my clinical writing is now knowing } \\
\text { improved in my ability to be concise and professional in my } \\
\text { grammar and sentence structure [use]. }\end{array}$ \\
\hline $\begin{array}{l}\text { Additional instruction, } \\
\text { experience necessary for } \\
\text { greater comfort, success } \\
\text { with clinical writing }\end{array}$ & $\begin{array}{l}\text { Heather explained that she had: ... improved the most in writing } \\
\text { Achieved clinical writing voice, and the least in writing assessment results. } \\
\text { goals }\end{array}$ \\
& $\begin{array}{l}\text { Sally indicated: Yes, my goals were met! Pre-workshop I used } \\
\text { passive voice a lot and had a hard time with word choice. I have } \\
\text { definitely noticed improvement because those words just come to } \\
\text { me now and I don't have to look them up! And, I rarely use passive } \\
\text { voice anymore. }\end{array}$ \\
& $\begin{array}{l}\text { Nora indicated success with clinical writing content goals, stating: } \\
\text { I wanted to write goals clearly and I was given tips to help me do } \\
\text { this. }\end{array}$ \\
\hline $\begin{array}{l}\text { Did not meet all clinical } \\
\text { writing goals }\end{array}$ & $\begin{array}{l}\text { When asked if her goals for the workshop had been met, Heather } \\
\text { stated: For the most part, some topics I'm still unsure about, but I } \\
\text { think that I just need more practice. }\end{array}$
\end{tabular}

\section{Discussion}

It was predicted that CWW participants would demonstrate improved selfregulation skills, especially in their ability to monitor their own clinical writing attempts as a result of their participation. This hypothesis was partially supported by the results of this study. Participants' pre- and post-intervention self-regulation was measured using clinical writing samples that were rated using the CWR. Specifically, elements of clinical writing use were measured to capture selfregulation during clinical writing. Analysis of the $C W R$ ratings indicated that while effects for time and attendance were positive, they were not significant. Despite a positive change in ratings from pre- to post-intervention, and a positive change in ratings for those with greater attendance of CWW sessions, these effects were not statistically significant. The items within this section of the $C W R$, are potential causes for the lack of significant changes. While participants demonstrated positive changes in these areas, it is likely that many may have been successful in these areas prior to the intervention (i.e. avoiding the use of first person, using appropriate grammar and spelling). Qualitative data supported the notion that participants did 
make gains in the area of self-regulation as related to clinical writing. Furthermore, participants reported (post-intervention) meeting and/or making progress towards clinical writing goals that they established for themselves (pre-intervention). Based on Schunk's (1989) definition, self-regulated learning occurs as a result of students focusing their thoughts and actions towards their educational goals; the CWW participants demonstrated self-regulated learning by making gains towards their clinical writing goals. In addition, participants' self-regulation changes were captured in field notes collected throughout the intervention. In summary, while ratings of clinical writing use on the $C W R$ did not indicate significant effects for time or attendance regarding participants' self-regulation, participants reported growth in clinical writing use skills, and progress towards goals established which both indicate self-regulatory changes.

It was also predicted that CWW participants would demonstrate improved clinical writing performance following engagement in critical thinking tasks during intervention. Results of this study supported this hypothesis. Participants' critical thinking was measured using clinical writing samples, pre- and post-intervention, that were rated using the $C W R$. Elements of clinical writing content were measured to identify critical thinking occurring during clinical writing. Analysis of the ratings indicated the effect for time was significant, while the effect for attendance was not. Based on these analyses, it can be concluded that participants made significant gains in critical thinking from pre- to post-intervention following participation in the CWW regardless of how many sessions they attended. The qualitative data collected via the post-intervention $C W Q$ also indicated that participants recognized changes in clinical writing skills specific to content that indicate growth in critical thinking, and the authors' field notes captured instances of critical thinking occurring throughout the CWW as well. Participation in class discussions, questions posed during CWW meetings, participants' critiques of writing samples and collaboration in problem solving efforts all gave evidence of participants' growth in critical thinking. In conclusion, both quantitative and qualitative data indicated participant growth in clinical writing skills as a result of engagement in critical thinking tasks included in the CWW.

\section{Implications}

The findings of this study have important implications regarding clinical writing instruction for graduate students studying speech-language pathology. Both quantitative and qualitative data indicate that the CWW approach to clinical writing instruction was generally successful in facilitating participants' growth in clinical writing self-regulation and critical thinking. As little research-based evidence regarding methods for building clinical writing skills for speech-language pathology students presently exists, graduate programs for speech-language 
pathologists may wish to consider approaches that include key features of the CWW to facilitate student growth within this writing genre (i.e., the use of models, writing practice, explicit instruction and feedback).

\section{Limitations}

Several limitations for the current study should be acknowledged. Specifically, the small $(\mathrm{n}=17)$ sample size likely limits the generalizability of the findings, as does the fact that all participants were all female, Caucasian, graduate students attending the same graduate school in the Midwest. Future research in this area should consider recruiting larger samples of more diverse participants across geographical locations.

The relationships of some of the participants with the CWW instructor also create further limitations on inferences that can be made from the current results. While most of the participants had no academic relationship with the instructor during the semester the CWW was conducted, two were directly supervised by the author during this semester, and, therefore received a grade for their clinical writing from the author during the intervention. The instructor's role, then, could have potentially impacted participation for these two students. In future studies, the instructor's relationship with students should be analyzed; a neutral party should direct clinical writing interventions.

Another limitation of the current study was the incomplete attendance participants demonstrated over the course of the CWW (see Appendix C for attendance record). Most participants $(n=10)$ attended fewer than five sessions, so this limited the amount of opportunities for writing practice, explicit instruction, and feedback for these participants. Although the data gathered indicated that participants made gains despite the number of sessions attended, it would certainly be beneficial for more participants to attend more of the sessions. In order to increase the likelihood of this occurring in future studies, careful attention should be paid as to when meetings are scheduled, as participants indicated that when the CWW was held limited attendance. The CWW sessions were held on Friday mornings; this was a day that students were not regularly required to be on campus for other commitments, therefore many opted to work, schedule medical appointments, leave town early for the weekend, etc. instead of coming to campus for the voluntary writing workshop. Furthermore, making the CWW a required course (or component of a required course) in future semesters could have a positive impact on attendance/participation as well.

The validity of the writing samples collected pre- and post-intervention is also of concern. In order for the study to advance, it was essential to collect writing samples 
that participants were already completing for their clinical assignments. Writing samples collected in this manner prevented the participants from having to complete additional writing assignments beyond their existing coursework requirements. The writing samples provided sound examples of the participants' pre-intervention clinical writing skill; however, post-intervention samples collected were not as accurate (pre-intervention samples were an initial draft that participants completed independently; post-intervention samples were completed with feedback provided outside of the CWW from clinical supervisors). While writing conditions for the participants were generally good (i.e., they had support from their supervisor, CWW instructor, and peers), the post-intervention sample is not a true indicator of independent growth via the CWW. Future research in this area should consider the use of additional, standard writing tasks to more accurately capture participant growth pre- to post-intervention.

Another potential limitation of the current study is that participants' clinical writing skills improvement may be attributed to factors beyond the CWW. Participants were full-time graduate students, enrolled in courses and working with clients within the university clinic. Lessons regarding clinical writing could have been addressed within their classes and clinical assignments that could have contributed to the participants' growth within this writing genre. Addressing clinical writing during a time when students are not enrolled in other classes, or clinic assignments should be considered in future studies.

\section{Conclusion}

The current study has provided important findings and generated additional questions regarding clinical writing instruction and the impact of a structured clinical writing intervention for graduate speech-language pathology students. The CWW has shown itself to be a potentially valuable intervention providing a possible vehicle for graduate student growth in self-regulation and critical thinking within clinical writing. Student development in these areas was likely supported by the use of instructional features such as models, writing practice, explicit instruction, and feedback. As little research is currently available regarding clinical writing instruction practices, this study contributes to the field in a unique way by offering insights into potentially effective instructional practices. Additional research is needed, however, to provide more comprehensive conclusions regarding ways to help graduate speech-language pathology students become effective clinical writers. Many possibilities exist for how programs can provide explicit instruction to facilitate student growth in this area. Incorporating a required CWW or specific course dedicated to clinical writing, implementing a clinical writing curriculum embedded within coursework, and/or developing self-guided online 
trainings are all options that should be further considered to advance our understanding of how to best help students grow as professional writers.

\section{References}

Abrami, P. C., Bernard, R. M., Borokhovski, E., Wade, A., Surkes, M. A., Tamim, R., \& Zhang, D. (2008). Instructional interventions affecting critical thinking skills and dispositions: A stage 1 meta-analysis. Review of Educational Research, 78(4), 1102-1134. doi:10.3102/0034654308326084

Baxley, B., \& Bowers, L. (1992). Clinical report writing: The perceptions of supervisors and supervisees. National Student Speech Language Hearing Association Journal, 19, 35-40.

Burrus, A.E., \& Willis, L.B. (2013). Professional communication in speechlanguage pathology: How to write, talk, and act like a clinician. San Diego, CA: Plural Publishing.

Butler, K.G., \& Silliman, E.R. (2002). Speaking, reading and writing in children with language learning disabilities: New paradigms in research and practice. Mahway, NJ: Lawrence Erlbaum Associations, Inc., Publishers.

Creswell, J.W., \& Plano Clark, V.L. (2011). Designing and Conducting Mixed Methods Research (2 ${ }^{\text {nd }}$ ed.). Thousand Oaks, CA: SAGE Publications.

Ennis, R. (1989). Critical thinking and subject specificity: Clarification and needed research. Educational Researcher, 18(3), 4-10. Retrieved from http://edr.sagepub.com/content/18/3/4.short

Fallahi, C.R., Wood, R.M., Austad, C.S., \& Fallahi, H. (2006). A program for improving undergraduate psychology students' basic writing skills. Teaching of Psychology, 33(3), 171-175.

Hallgren, K.A. (2012). Computing inter-rater reliability for observational data: An overview and tutorial. Tutorials in Quantitative Methods for Psychology, 8(1), 23-34.

Hegde, M.N. (1994). A coursebook on scientific and professional writing for speech-language pathology: Third edition. Clifton Park, NY: Delmar.

Hegde, M.N. (2010). A coursebook on scientific and professional writing for speech-language pathology: Fourth edition. Clifton Park, NY: Delmar.

Loyens, S. M. M., Magda, J., \& Rikers, R. M. J. P. (2008). Self-directed learning in problem-based learning and its relationships with self-regulated learning. Educational Psychology Review, 20(4), 411-427. doi:10.1007/s10648-0089082-7

Pannbacker, M. (1975). Diagnostic report writing. Journal of Speech and Hearing Disorders, 40(3), 367-380. Retrieved from http://jshd.asha.org/cgi/content/abstract/40/3/367

Plante, E. (2010). Developing writing skills in our students. Presented at Council of Academic Programs in Communication Sciences and Disorders Annual 
Conference.

Acquired

from www.capcsd.org/proceedings/2010/talks/plante2010.pdf.

Plante, E. (2011). Writing skills development across the discipline. Presented at Council of Academic Programs in Communication Sciences and Disorders Annual Conference. Acquired from www.capcsd.org/proceedings/2011/talks/2011_CAPCSD_Plante.pdf.

Rawson, R.E., Quinlan, K.M., Cooper, B.J., Fewtrell, C., \& Matlow, J.R. (2005). Writing skills development in the health professions. Teaching and Learning in Medicine, 17(3), 233-239.

Schunk, D. (1989). Social cognitive theory and self-regulated learning. In B.J. Zimmerman \& D.H. Schunk (Eds.), Self-regulated learning and academic achievement: Theory, research and practice (pp. 83-110). Retrieved from http://link.springer.com/chapter/10.1007/978-1-4612-3618-4_4

Sitler, H.C. (1993). What college writing instructors expect and why you should join the resistance. The English Journal, 82(6), 21-25.

Smith, T., Ariail, J., Richards-Slaughter, S., \& Kerr, L. (2011). Teaching professional writing in an academic health sciences center: The writing center model at the Medical University of South Carolina. Teaching and Learning in Medicine, 23(3), 298-300.

Terenzini, P., Springer, L., Pascarella, E.T., \& Nora, A. (1995). Influences affecting the development of students' critical thinking skills. Research in Higher Education, 36(1), 23-39. Retrieved from http://www.springerlink.com/index/K423477R5H25U5WU.pdf

Tsui, L. (2002). Fostering critical thinking through effective pedagogy: Evidence from four institutional case studies. The Journal of Higher Education, 73(6), 740-763. Retrieved from http://muse.jhu.edu/journals/jhe/summary/v073/73.6tsui.html

Wilkerson, D.L. (2000). Documenting clinical service delivery: Writing style and lexical selection. Contemporary Issues in Communication Science and Disorders, 27, 6-13.

Zimmerman, B. (2002). Becoming a self-regulated learner: An overview. Theory into Practice, 41(2), 64-70. Retrieved from http://www.tandfonline.com/doi/pdf/10.1207/s15430421tip4102_2

Zimmerman, B., \& Bandura, A. (1994). Impact of self-regulatory influences on writing course attainment. American Educational Research Journal, 31(4), 845-862. Retrieved from http://aer.sagepub.com/content/31/4/845.short

Zimmerman, B.J., \& Schunk, D. H. (2011). Self-regulated learning and performance: An overview. In B.J. Zimmerman \& D.H. Schunk (Eds.), Handbook of self-regulation of learning and performance (pp. 1-14). London: Routledge. 
Teaching and Learning in Communication Sciences \& Disorders, Vol. 1 [2017], Iss. 1, Art. 3

https://ir.library.illinoisstate.edu/tlcsd/vol1/iss1/3 


\section{Appendix A}

\section{Clinical Writing Questionnaires \& Interview Questions}

\section{Pre-Intervention Questionnaire:}

1. What are specific goals do you have going into this clinical writing workshop?

2. What are your areas of strength within the domain of clinical writing?

3. What are your areas of weakness within the domain of clinical writing?

4. Describe any previous instruction that you have had regarding clinical writing.

5. Describe your previous experience with clinical writing (i.e., How many clients have you written about clinically? Have you completed clinical writing assignments for classes? Etc.)

\section{Pre-Intervention Interview Questions:}

1. Describe your previous experiences with clinical writing.

2. Why did you decide to participate in the clinical writing workshop?

3. How do you feel about clinical writing at this time? (i.e., positive, negative, neutral)

4. Explain how confident you are about completing clinical writing tasks.

What are your goals for the clinical writing workshop?

\section{Post-Intervention Questionnaire:}

1. Were your specific goals met over the course of the clinical writing workshop? Why or why not?

2. Describe what you liked about the Clinical Writing Workshop. Include a description of what was most helpful regarding this experience (e.g., writing practice, peer critiques, instructor feedback, instructional lessons, etc.)

3. Describe areas that you feel could have been improved upon in the Clinical Writing Workshop.

4. Are there any additional topics that you believe should be included in this workshop? Explain.

5. Would you eliminate any of the topics covered in this workshop? Explain.

6. Comment on the length on the workshop (number of sessions, length of sessions). Were there a sufficient number of sessions? Were they long enough?

7. Indicate any recommendations you have based on your experience with this program that should be considered for future sessions.

\section{Post-Intervention Interview Questions:}


1. Describe your experience participating in the clinical writing workshop.

2. Did participating in the workshop change your feelings towards clinical writing?

3. Do you feel more confident in your clinical writing after participating in the workshop? Explain.

4. How has your clinical writing changed as a result of your participation in the workshop? Where have you improved the most/least?

5. What did you think about the content of the workshop?

6. Was the format of the workshop effective?

7. What was most helpful about the workshop?

8. What was least helpful about the workshop? 


\section{Appendix B \\ Clinical Writing Rubric}

\section{Clinical Writing Rubric}

Rate student's clinical writing attempt in the following areas: Professional writing style, inclusion of pertinent information, clarity of message, explanation of assessment results, appropriate recommendations, and synthesis of information.

Ratings range from $0-5$ with the following criteria assigned to each:

$0=$ Not Applicable

$1=$ Standard not met within this document

$2=$ Standard rarely met in portions of the document (evidence present once or twice throughout)

$3=$ Standard occasionally met in portions of the document (evidence present at least three to four times throughout)

$4=$ Standard met with few exceptions throughout document (evidence in all but one to two occasions throughout document)

$5=$ Standard met consistently throughout document (evidence in entire document)

\begin{tabular}{|l|l|l|l|l|l|l|}
\hline & $\mathbf{5}$ & $\mathbf{4}$ & $\mathbf{3}$ & $\mathbf{2}$ & $\mathbf{1}$ & $\mathbf{0}$ \\
\hline Use: (Clinical Writing Style): & & & & & & \\
\hline 1. Avoids use of first person & & & & & & \\
\hline 2. Writes objectively & & & & & \\
\hline 3. Uses correct mechanics, grammar & & & & & \\
\hline 4. Uses active voice & & & & & & \\
\hline 5. Writes in a straight-forward manner, avoiding ambiguity & & & & & \\
\hline 6. Writes concisely & & & & & \\
\hline $\begin{array}{l}\text { 7. Uses appropriate professional vocabulary (in reader-friendly } \\
\text { manner) }\end{array}$ & & & & & \\
\hline Content: & & & & & \\
\hline $\begin{array}{l}\text { 1. Includes relevant information regarding client's current level of } \\
\text { performance }\end{array}$ & & & & & \\
\hline 2. Includes relevant information regarding client's history & & & & & \\
\hline $\begin{array}{l}\text { 3. Formal assessment results explained well (e.g., standard scores } \\
\text { presented with explanation of SD, mean) }\end{array}$ & & & & & \\
\hline $\begin{array}{l}\text { 4. Informal assessment measures explained well (e.g., procedures } \\
\text { described, findings/ significance reported) }\end{array}$ & & & & & \\
\hline 5. Establish appropriate, measureable goals for clients & & & & & & \\
\hline 6. Thorough rationale included for each goal (when applicable) & & & & & & \\
\hline $\begin{array}{l}\text { 7. Includes appropriate recommendations matching client's } \\
\text { assessment results as well as developmental and communication needs } \\
\text { (final report / post-test writing attempt only) }\end{array}$ & & & & & & \\
\hline Form: & & & & \\
\hline 1. Information is presented in a logical, organized manner & & & & & & \\
\hline $\begin{array}{l}\text { 2. Information synthesized across sections of report (e.g., formal and } \\
\text { informal measures are compared) }\end{array}$ & & & & & \\
\hline
\end{tabular}




\section{Appendix C}

\section{Clinical Writing Workshop Schedule}

\begin{tabular}{|c|c|c|c|}
\hline & Topic & Tasks & Attendance \\
\hline 1 & $\begin{array}{l}\text { Information } \\
\text { al Meeting }\end{array}$ & $\begin{array}{l}\text { 1. Author discussed format, schedule, purpose for } \\
\text { workshop } \\
\text { 2. Graduate assistant obtained consent forms (to ensure } \\
\text { anonymity; participants in the workshop were not } \\
\text { required to participate in study) }\end{array}$ & 18 present \\
\hline 2 & $\begin{array}{l}\text { Self- } \\
\text { Efficacy }\end{array}$ & $\begin{array}{l}\text { 1. All completed pre-intervention tasks (including } \\
\text { questionnaire, establish personal clinical writing goals } \\
\text { for the semester) } \\
\text { 2. Discussed topics of interest } \\
\text { 3. Self-Efficacy lesson, followed by discussion }\end{array}$ & 17 present \\
\hline 3 & $\begin{array}{l}\text { Clinical } \\
\text { Writing } \\
\text { Style }\end{array}$ & $\begin{array}{l}\text { 1. Lesson re: concise and direct writing, wordiness } \\
\text { 2. Practice writing task } \\
\text { 3. Peer critique }\end{array}$ & 16 present \\
\hline 4 & $\begin{array}{l}\text { Clinical } \\
\text { Writing } \\
\text { Style }\end{array}$ & $\begin{array}{l}\text { 1. Discussion re: how to provide feedback for peers } \\
\text { 2. Writing lab; application of lesson } \\
\text { 3. Peer critiques of actual clinical writing attempts }\end{array}$ & 6 present \\
\hline 5 & $\begin{array}{l}\text { Clinical } \\
\text { Writing } \\
\text { Content }\end{array}$ & $\begin{array}{l}\text { 1. Electronic submission of pre-intervention writing } \\
\text { samples conducted } \\
\text { 2. Writing measureable goals lesson } \\
\text { 3. Practice task } \\
\text { 4. Application to own clinical writing } \\
\text { 5. Feedback from instructor (as sought) }\end{array}$ & 14 present \\
\hline 6 & $\begin{array}{l}\text { Clinical } \\
\text { Writing } \\
\text { Style }\end{array}$ & $\begin{array}{ll}\text { 1. } & \text { Passive vs. active voice lesson } \\
\text { 2. } & \text { Practice task } \\
\text { 3. } & \text { Apply to own writing } \\
\text { 4. } & \text { Peer critique } \\
\text { 5. } & \text { Feedback from instructor (as sought) }\end{array}$ & 6 present \\
\hline 7 & $\begin{array}{l}\text { Clinical } \\
\text { Writing } \\
\text { Style }\end{array}$ & $\begin{array}{l}\text { 1. Word choice lesson (handouts provided, discussion } \\
\text { followed) } \\
\text { 2. Practice task (completed worksheet, pair shared, } \\
\text { discussed) } \\
\text { 3. Application to own clinical writing } \\
\text { 4. Feedback from instructor (as sought) }\end{array}$ & 10 present \\
\hline 8 & $\begin{array}{l}\text { Clinical } \\
\text { Writing } \\
\text { Style }\end{array}$ & $\begin{array}{l}\text { 1. Review of style components covered thus far } \\
\text { 2. Application to own clinical writing } \\
\text { 3. Feedback from instructor (as sought) }\end{array}$ & 7 present \\
\hline 9 & $\begin{array}{l}\text { Clinical } \\
\text { Writing } \\
\text { Content }\end{array}$ & $\begin{array}{l}\text { 1. Mid-intervention goal progress checkpoint } \\
\text { 2. Reporting assessment results lesson (handouts, } \\
\text { discussion, strong/weak models) }\end{array}$ & 5 present \\
\hline 10 & $\begin{array}{l}\text { Clinical } \\
\text { Writing } \\
\text { Content }\end{array}$ & $\begin{array}{l}\text { 1. Further discussion re: Reporting Assessment Results } \\
\text { 2. Application task (Case Study) } \\
\text { 3. Instructor feedback }\end{array}$ & 5 present \\
\hline
\end{tabular}




\begin{tabular}{|c|c|c|c|}
\hline 11 & $\begin{array}{l}\text { Clinical } \\
\text { Writing } \\
\text { Content }\end{array}$ & $\begin{array}{l}\text { 1. Summary and Recommendations Lesson } \\
\text { 2. Application to case study } \\
\text { 3. Instructor feedback }\end{array}$ & 3 present \\
\hline 12 & $\begin{array}{l}\text { Clinical } \\
\text { Writing } \\
\text { Content }\end{array}$ & $\begin{array}{l}\text { 1. Review of content components covered } \\
\text { 2. Application to own clinical writing assignments } \\
\text { 3. Instructor feedback }\end{array}$ & 4 present \\
\hline 13 & $\begin{array}{l}\text { Open } \\
\text { Writing Lab }\end{array}$ & $\begin{array}{l}\text { 1. Application of information from workshop to actual } \\
\text { clinical writing assignments (e.g., End-of-Semester } \\
\text { Reports) }\end{array}$ & 4 present \\
\hline 14 & $\begin{array}{l}\text { Post- } \\
\text { Intervention } \\
\text { Data } \\
\text { Collection }\end{array}$ & 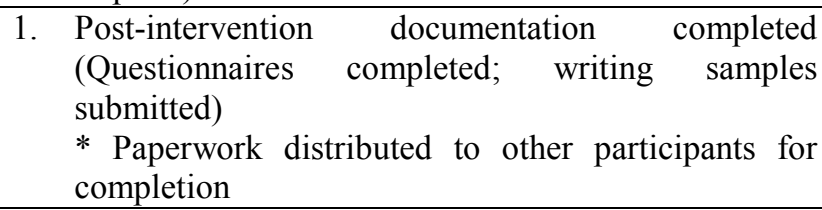 & 3 present* \\
\hline
\end{tabular}

